\title{
Effect of Different Temperatures on Colony Characteristics of Bombus terrestris (Hymenoptera: Apidae)
}

\author{
Muhammad Nasir',*, Ata-ul-Mohsan², Munir Ahmad ${ }^{2}$, Shafqat Saeed ${ }^{3}$, \\ Muhammad Asif Aziz ${ }^{2}$, Muhammad Imran ${ }^{4}$ and Umer Ayyaz Aslam Sheikh \\ ${ }^{1}$ Department of Entomology, The University of Haripur, Haripur, KPK \\ ${ }^{2}$ Department of Entomology, PMAS-Arid Agriculture University, Rawalpindi \\ ${ }^{3}$ Department of Entomology, Muhammad Nawaz Sharif University of Agriculture, Multan \\ ${ }^{4}$ Department of Entomology, University of the Poonch Rawalakot, AJ\&K
}
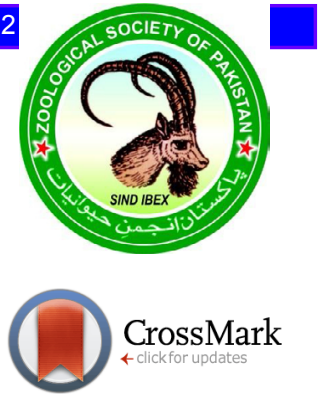

\begin{tabular}{|c|}
\hline Article Information \\
\hline Received 19 January 2017 \\
\hline Revised 11 May 2018 \\
\hline Accepted 06 August 2018 \\
\hline Available online 02 May 2019 \\
\hline Authors' Contribution \\
\hline $\begin{array}{l}\text { MN, AM and MA designed and } \\
\text { executed the research and wrote } \\
\text { the article. MI and UAAS helped in } \\
\text { establishment of bumblebee culture } \\
\text { and collection of data. AA and SS } \\
\text { helped in data analysis. }\end{array}$ \\
\hline Key words \\
\hline $\begin{array}{l}\text { Bombus terrestris, Colony initiation, } \\
\text { Colony development, Rearing, } \\
\text { Temperature. }\end{array}$ \\
\hline
\end{tabular}

\section{INTRODUCTION}

$\mathrm{P}$ ollinators provide key ecosystem services that empower plant to produce fruits and seeds. Bumblebees are most important pollinators of agriculture both in open field conditions and protected farming systems (Corbet et al., 1991; Ahmad et al., 2015). These pollinators bees are often described as primitively eusocial insects which possess 300 species. Latest classifications place all of the identified species in a single genus Bombus meaning 'booming' (Prys-Jones and Corbet, 1991). These are mainly confined to temperate regions of the world due to their certain temperature requirement (Williams, 2007).

Greenhouse tomato (Solanum lycopersicum L.) is the key crop pollinated by bumblebees globally (Dogterom et al., 1998; Morandin et al., 2001; Winter et al., 2006). Until present, pollination of glasshouse tomatoes has been carried out by hand with a vibrating wand, no doubt a very tedious job and expensive in terms of labour (Cribb, 1990). Worldwide, about $95 \%$ of bumblebee sales are for greenhouse tomato which comprises a more than 40,000 hectares of greenhouse crops. Tomato crop in greenhouse culture is usually grown all the year which require more than 50 bumblebee hives per hectare. The value of these

\footnotetext{
Corresponding author: nasir.uaar@gmail.com 0030-9923/2019/0004-1315 \$ 9.00/0

Copyright 2019 Zoological Society of Pakistan
}

bumblebee pollinated tomato crops is estimated to be $€$ 12000 million per year (Velthuis and van Doorn, 2006).

On a commercial scale, bumblebee rearing started in 1987 and has been available in portable boxes for crop pollination (Mitsuhata, 2000). Worldwide there are about more than 30 Bombi-culture industries but most of the market share is captured by three companies. Koppert Biological Systems (Netherland), Biobest (Belgium) and BBB (Bunting Brinkman Bees, Netherlands) are the biggest producers of bumblebee in the world (Velthuis and van Doorn, 2006).

European bumblebee, Bombus terrestris is the most preferred species for bumblebee breeder. It is easily available in Europe where the technique for year round rearing and commercial production has evolved (Velthuis and van Doorn, 2006). Large colony size, wide distribution, adaptability to diverse climatic condition, habitats and flower types makes it a hardy and efficient pollinator favoured in commercial rearing (Velthuis and van Doorn, 2006). It can visit 20 to 50 simple, small flowers per minute and in the case of red clover between 20 to 35 flowers per minute (Free, 1993).

Bombus terrestris is univoltine in nature and its life cycle has two phase (i) solitary phase and (ii) social phase. B. terrestris colonies are comprised of different caste for their reproductive, foraging, defence and other tasks necessary for their survival. In the solitary phase of their life cycle, queens enter the diapauses after successful 
mating in fall and after emergence from diapauses in spring, queens start foraging and looking for appropriate nest sites for oviposition. In the social phase of development, the majority of tasks of colony performed by the emerging workers and queen perform mostly reproductive work. Towards the end of colony cycle, young queens and males are produced. After successful mating young queen enters into the diapause and rest of the colony collapses (Lopez et al., 2009; Prŷs-Jones and Corbet, 2011).

Different factors like rearing conditions, nest material and diet play important role in artificial rearing of this important pollinator (Yoon et al., 2002, 2005; Imran et al., 2017). Commercial scale rearing of bumblebees requires efficiency in rearing processes to enhance their utilization for the benefit of farmers. Temperature plays an important role in the regulation of growth and development and affecting almost every aspect of life (Obrycki and Tauber, 1981; Srivastava and Omkar, 2003; Omkar and Pervez, 2004; Pervez and Omkar, 2004). Life duration, oviposition and diapause are some most important aspects which are under the influence of temperature changes. Change in temperature from ambient level showed marked variation in egg development time of Sitotroga cerealella (Oliver) (Perez-Mendoza et al., 2004). Similarly, oviposition rate of Periplaneta japonica and diapause termination in bumblebees showed temperature influence with desired development under ambient level for different life stages need (Alford, 1969; Tanaka and Uemura, 1996).

Oviposition and production of sexuals of bumblebees have shown the influence of temperature (Tasei, 1994; Yoon et al., 2002). Previous studies have recommended the different range of temperature for artificial rearing of the bumblebee. The present study was planned with the objective to find favourable exposure temperature for the survival of the post- hibernated queens after flight activity period and their impact on colony initiation and further colony development.

\section{MATERIALS AND METHODS}

\section{Experimental insect}

Post-hibernated queens of $B$. terrestris were used in this experiment. Queens were collected from the mass rearing system of Non-Apis Bee Laboratory, Department of Entomology, Pir Mehr Ali Shah, Arid Agriculture University Rawalpindi. During activation period of one week, queens were subjected to the flight cages $(40 \times 40 \times 60$ $\mathrm{cm})$ under white light conditions. The ground of flight cage was covered with filter paper and provided with sugar syrup and pollen as a diet source of queens.

\section{Temperature treatments}

There were five different temperature treatments that were used in this experiment that include $24{ }^{\circ} \mathrm{C}, 26{ }^{\circ} \mathrm{C}, 28$ ${ }^{\circ} \mathrm{C}, 30^{\circ} \mathrm{C}$ and $32{ }^{\circ} \mathrm{C}$. Queens in these cages were randomly subjected to one of the temperature treatment and relative humidity for all the five temperatures was maintained at $60 \pm 10 \%$. Temperature and relative humidity for all the applied treatments were checked on a daily basis by using a thermo-hygrometer.

\section{Colony initiation and development}

After one week of flight activity in cages, those queens who rubbed their abdomen on the base of flight cages were transferred to the small transparent plastic box. The ground of the starter boxes was covered with cardboard material. To stimulate oviposition, queens in the starter boxes were provided with previously frozen dead pupa that had been horizontally fixed with glue on the ground of cardboard material (Kwon et al., 2003; Gurel and Gosterit, 2008), and two small sized helper workers of the Bombus terrestris were also provided to the queen in starter box.

Starter boxes were again subjected to the respective temperature treatment chamber. Pollen and sugar solution were provided to the queens in the starter boxes on daily basis. Queens in the starter boxes were monitored on daily basis for observation of colony initiation time.

Queens started egg lying on pupa or on the ground of cardboard material and workers helped the queen in the initiation of egg lying. Helper workers were removed/replaced every week until the queen started egg laying. When queens started oviposition, helper workers were removed. Starter boxes remained in the relevant temperature condition until the emergence of first brood workers.

Colonies were shifted to the larger boxes after the emergence of worker of the first batch. The larger colony boxes were connected with sugar solution container via wick present at the bottom. Rest of colony development was completed in larger boxes in a controlled room (Temperature $=27{ }^{\circ} \mathrm{C}$; Relative humidity $=60 \pm 10 \%$ ) in complete darkness except when colonies were being observed. Illuminated red light with minimum light intensity at which observation was possible to observe different life history parameters (bumblebees are colour blind to red light).

\section{Observation of parameters}

Following parameters were observed in this study: (i) Survival rate and colony initiation rate of the queens. (ii) Pre-oviposition period. (iii) Number of egg cells in first brood. (iv) First brood size. (v) Emergence timing of first worker, males and progeny queen in a colony. (vi) 
Switch point and Competition point. (vii) Total number of workers, males and progeny queens produced in a colony. (viii) Lifespan of founding queen, and (ix) Energy spent on sexuals was calculated by using the following formula:

$$
\text { Energy spent on sexuals }=
$$

$($ No. of queens $\times 7.83 \mathrm{~kJ})+($ No. of males $\times 2.35 \mathrm{~kJ})$ As $7.83 \mathrm{~kJ}$ and $2.35 \mathrm{~kJ}$ of energy are required to produce one queen and male, respectively (Beekman and van Stratum, 1998).

\section{Data analysis and statistic}

Data of different life parameters were analyzed using analysis of variation and means were compared with t-test at 5\% probability. Chi-squares analysis was performed using SPSS programs (Norus, 2006).

\section{RESULTS}

\section{Survival rate in flight cage}

Figure 1 shows the survival and colony initiation rate of queens, pre-oviposition periods, production of egg cells and brood size in first batch, emergence timing of
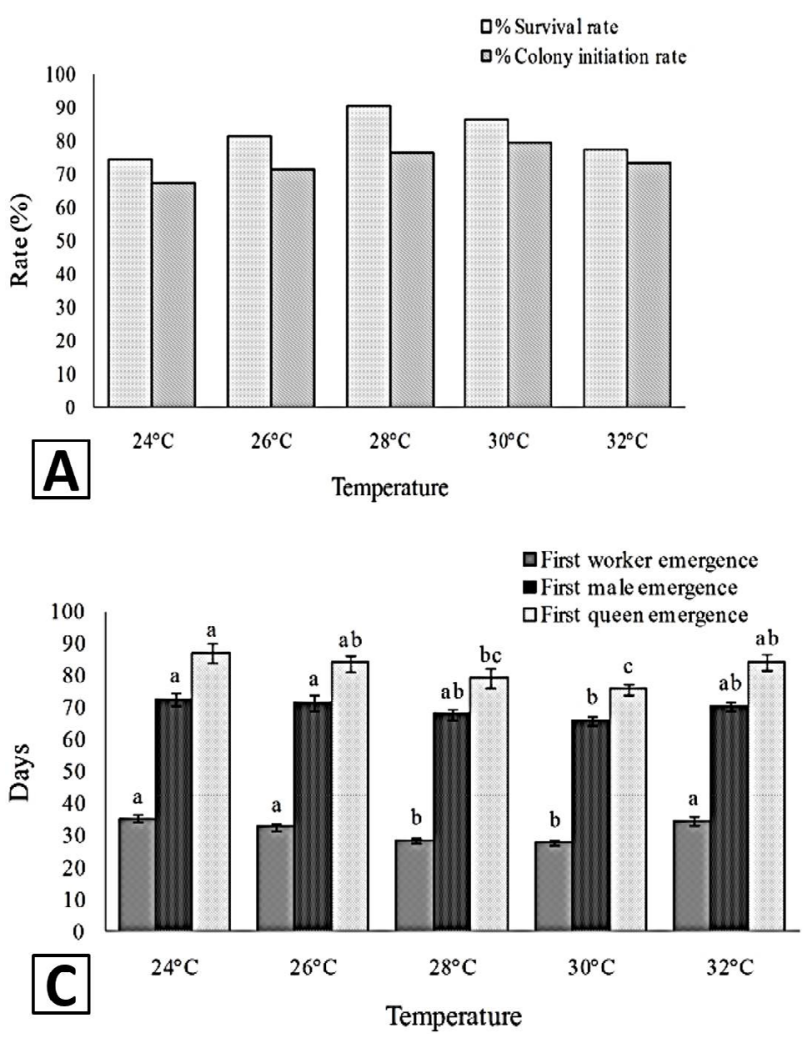

first worker, male and daughter queen, and total number of workers, males and progeny queens produced for Bombus terrestris.

Highest survival rate of queens was observed at $28^{\circ} \mathrm{C}$ with $90 \%$ queens and the lowest at $24^{\circ} \mathrm{C}$ with $74 \%$ queens (Fig. 1A). Temperature above and below $28^{\circ} \mathrm{C}$ resulted in decreased progeny queens inside flight cage kept for flight activity period. The highest colony initiation rate was observed at $30^{\circ} \mathrm{C}(79 \%)$ while it was lowest at $24^{\circ} \mathrm{C}(67 \%)$.

Significant difference existed for pre-oviposition period of $B$. terrestris queens at five different temperatures ranging $24-32^{\circ} \mathrm{C}$ (Fig. 1B). Shortest pre-oviposition period (6.1 \pm 1.15 days) was observed at $30^{\circ} \mathrm{C}$ while longest preoviposition period (14.9 \pm 1.1 days) was observed at $24^{\circ} \mathrm{C}$ $\left(\mathrm{F}_{(4,49)}=8.16, \mathrm{P}=0.0000\right)$. Number of egg cells produced in first brood differed significantly with the highest at $30^{\circ} \mathrm{C}$ (3.1 \pm 0.31$)$ and the lowest at $24{ }^{\circ} \mathrm{C}(1.9 \pm 0.23)$ (Fig. 1B) (F $(4,49)=3.66, \mathrm{P}=0.0115)$. Number of workers in first brood was significantly higher at $28{ }^{\circ} \mathrm{C}(7.9 \pm 0.45)$ which was insignificant at $26{ }^{\circ} \mathrm{C}$ and $30^{\circ} \mathrm{C}(7.2+0.62$ and $7.5+0.5)$. It was significantly lower at $24^{\circ} \mathrm{C}(5.6 \pm 0.30)\left(\mathrm{F}_{(4,49)}=3.81\right.$, $\mathrm{P}=0.0094)$ (Fig. 1B).

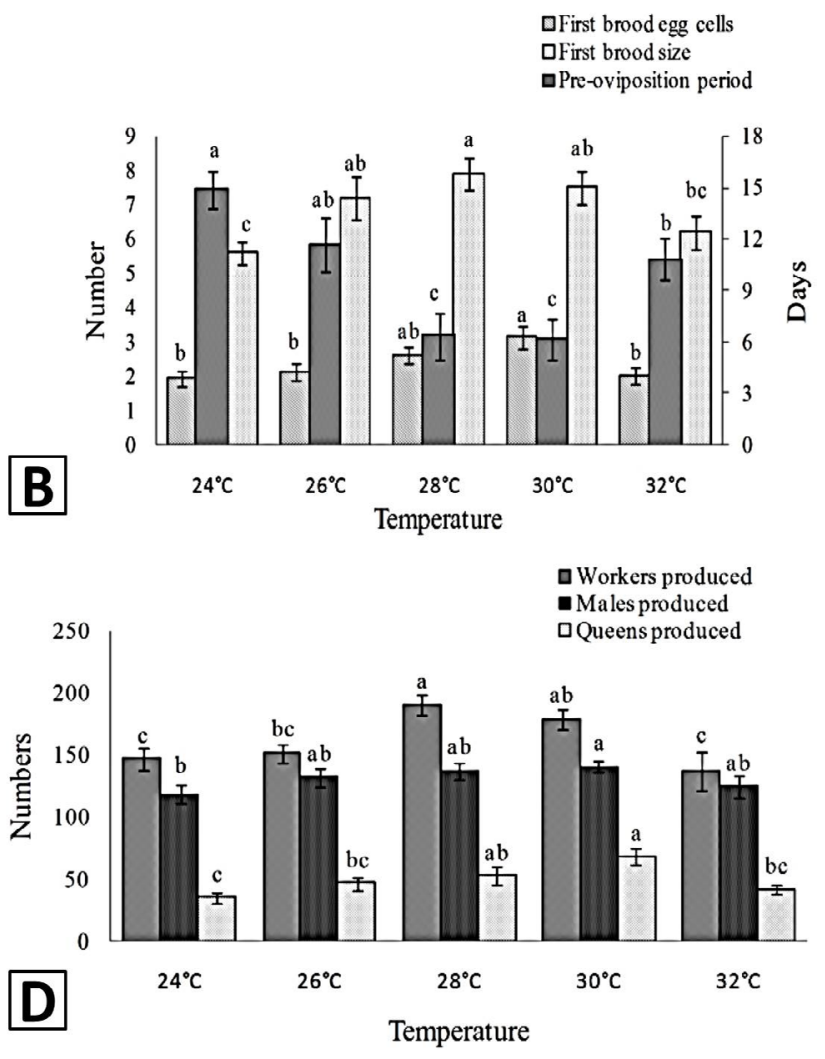

Fig. 1. Effect of different exposure temperatures on: survival and colony initiation rate of queens (A), pre-oviposition periods, production of egg cells and brood size in first batch (B), emergence timing of first worker, male and daughter queen (C), and total number of workers, males and progeny queens produced (D) for Bombus terrestris. 
Table I.- Effect of temperature treatments on different characteristics of $\boldsymbol{B}$. terrestris colony.

\begin{tabular}{lccccc}
\hline Parameters observed & \multicolumn{5}{c}{ Exposure temperature } \\
\cline { 2 - 6 } & $\mathbf{2 4}^{\mathbf{0}} \mathbf{C}$ & $\mathbf{2 6}^{\mathbf{}} \mathbf{C}$ & $\mathbf{2 8}^{\mathbf{}} \mathbf{C}$ & $\mathbf{3 0}^{\mathbf{}} \mathbf{C}$ & $\mathbf{3 2}^{\mathbf{}} \mathbf{C}$ \\
\hline Switch point (days) & $37.7 \pm 2.07 \mathrm{a}$ & $39.1 \pm 2.48 \mathrm{a}$ & $39.5 \pm 1.91 \mathrm{a}$ & $38.3 \pm 1.3 \mathrm{a}$ & $36.2 \pm 1.7 \mathrm{a}$ \\
Competition point (days) & $42.7 \pm 2.04 \mathrm{a}$ & $43.8 \pm 2.42 \mathrm{a}$ & $47.9 \pm 2.04 \mathrm{a}$ & $48.6 \pm 2.65 \mathrm{a}$ & $44.6 \pm 1.65 \mathrm{a}$ \\
Queen longevity (days) & $98.8 \pm 3.55 \mathrm{bc}$ & $105.2 \pm 4.18 \mathrm{abc}$ & $110.8 \pm 5.43 \mathrm{ab}$ & $113.7 \pm 6.15 \mathrm{a}$ & $96.9 \pm 3.62 \mathrm{c}$ \\
Energy spent on sexual (KJ) & $497.55 \pm 46.32$ & $670.45 \pm 48.42$ & $728.48 \pm 65.39$ & $859.79 \pm 56.54$ & $616.26 \pm 39.32$ \\
\hline
\end{tabular}

Data expressed as Mean \pm S.E. Means followed by different letter are significantly different $(\mathrm{P} \leq 0.05)$.

The emergence timing of first worker was observed shortest at $30{ }^{\circ} \mathrm{C}(27.70 \pm 0.93$ days $)$ insignificant to 28 ${ }^{\circ} \mathrm{C}(28.4 \pm 0.92)$ but significantly different at other three temperature treatments. It was $35.1 \pm 1.14$ days at $24^{\circ} \mathrm{C}$, $32.6 \pm 1.29$ days at $26^{\circ} \mathrm{C}$ and $34.4 \pm 1.19$ days at $32{ }^{\circ} \mathrm{C}\left(\mathrm{F}_{(4,}\right.$ ${ }_{49)}=9.48, \mathrm{P}=0.0000$ ) (Fig. 1C). Insignificant difference in the emergence timing of males was observed. However, it was shortest at $30{ }^{\circ} \mathrm{C}(66.00 \pm 1.22$ days $)$ and longest at $24{ }^{\circ} \mathrm{C}(72.80 \pm 2.03$ days $)\left(\mathrm{F}_{(4,49)}=2.38, \mathrm{P}=0.0653\right)$ (Fig. $1 \mathrm{C})$. Difference in emergence timing of daughter queens was significant with shortest at $30^{\circ} \mathrm{C}(75.80 \pm 1.82$ days $)$. It was statistically different to that at $24^{\circ} \mathrm{C}, 26^{\circ} \mathrm{C}$ and 32 ${ }^{\circ} \mathrm{C}$ but differed insignificantly to that at $28^{\circ} \mathrm{C}$. It took more time at $24^{\circ} \mathrm{C}(87.10 \pm 2.87$ days $)\left(\mathrm{F}_{(4,49)}=3.02, \mathrm{P}=0.0273\right)$ (Fig. 1C).

Total number of workers produced varied significantly by temperature exposures $\left(\mathrm{F}_{(4,49)}=4.89, \mathrm{P}=0.0023\right)$ (Fig.1D). Highest number of workers were produced at $28{ }^{\circ} \mathrm{C}(190 \pm 7.82)$, statistically similar to that at $30{ }^{\circ} \mathrm{C}$ but significantly different from that at $24{ }^{\circ} \mathrm{C}, 26{ }^{\circ} \mathrm{C}$ and $32{ }^{\circ} \mathrm{C}$. Lowest number of workers was produced at 32 ${ }^{\circ} \mathrm{C}(137 \pm 15.9)$. Production of males was insignificantly

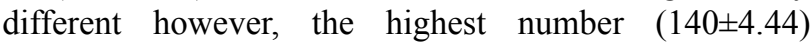
produced at $30{ }^{\circ} \mathrm{C}$ and the lowest number $(118 \pm 7.37)$ at $24{ }^{\circ} \mathrm{C}\left(\mathrm{F}_{(4,49)}=1.79, \mathrm{P}=0.1480\right)$ (Fig. 1D). Production of daughter queens was significantly affected by temperature treatments with the highest $(67.7 \pm 6.72)$ produced at $30^{\circ} \mathrm{C}$. Lowest production of daughter queens $(34.70 \pm 4.83)$ was observed at $24{ }^{\circ} \mathrm{C}\left(\mathrm{F}_{(4,49)}=4.74, \mathrm{P}=0.0028\right)$ (Fig. 1D).

Table I shows different temperature on switch points, competition points, energy spent on sexuals and life span of founding queens of $B$. terrestris. There existed insignificant difference in occurrence of switch point at five different exposure temperatures $\left(\mathrm{F}_{(4,49)}=0.45\right.$, $\mathrm{P}=0.7713)$. It took 36-39 days to switch from worker to sexual production in colonies under observation at all temperatures. Insignificant difference was observed in the occurrence of competition point at five different temperatures ranging from $24-32^{\circ} \mathrm{C}$. However, it occurred earlier at $24{ }^{\circ} \mathrm{C}(42.70 \pm 2.04$ days $)$ and late at $30^{\circ} \mathrm{C}(48.60$ \pm 2.65 days $)\left(\mathrm{F}_{(4,49)}=1.40, \mathrm{P}=0.2491\right)$. Amount of energy spent on production of sexuals at different temperatures showed $860 \mathrm{KJ}$, spent on production of sexuals at 30 ${ }^{\circ} \mathrm{C}$, the highest among all the temperature treatments. The lowest was $498 \mathrm{KJ}$, spent at $24{ }^{\circ} \mathrm{C}$. There existed insignificant effect of different temperature treatments on lifespan of mother queen. However, it was the longest at $30{ }^{\circ} \mathrm{C}(113 \pm 6.15$ days $)$ and $98.8 \pm 3.55$ days at $24{ }^{\circ} \mathrm{C}$ and shortest at $32^{\circ} \mathrm{C}(96.9 \pm 3.62$ days $)\left(\mathrm{F}_{(4,49)}=2.41, \mathrm{P}=0.634\right)$.

\section{DISCUSSION}

Among all the abiotic factors, temperature plays a vital role in growth and development of many beneficial insects especially B. terrestris reared on a commercial scale for pollination purpose (Obrycki and Tauber, 1981). Optimal development conditions are very much necessary to increase the efficiency of its mass rearing. In nature, after emergence from the diapause in spring, queen starts foraging flight for 10-15 days and search for a suitable place for initiation of its colony (Velthuis and van Doorn, 2006). The present study focused on observing the effect of five different exposure temperatures to colony initiation, growth and reproductive behavior of $B$. terrestris queens.

Results from our experiment showed that $28^{\circ} \mathrm{C}$ and $30{ }^{\circ} \mathrm{C}$ temperatures showed the highest survival rate of queens after flight period of one week $(90 \%$ and $86 \%$, respectively). The highest percentage of the colony was initiated at $30{ }^{\circ} \mathrm{C}$. For early colony initiation and survival rate, $30{ }^{\circ} \mathrm{C}$ was observed most suitable with $86 \%$ queen kept on egg laying (Gurel and Gosterit, 2008). Highest colony initiation (egg laid) and colony production ratio were also observed at the same temperature with $60 \% \mathrm{RH}$ (Jie et al., 2005). However, there existed some variation for another species, $B$. ignitus queens with highest colony initiation percentage $(83 \%)$ at $27^{\circ} \mathrm{C}$ with $65 \% \mathrm{RH}$ (Yoon et al., 2002).

In the artificial rearing of $B$. terrestris, the most important stage after the diapause of queens is colony initiation (Velthuis and van Doorn, 2006). Queen with the shortest pre-oviposition period (colony initiation period) is considered very important having strong production 
abilities. We observed significantly shorter pre-oviposition period at $28{ }^{\circ} \mathrm{C}$ and $30{ }^{\circ} \mathrm{C}(6.30 \pm 1.35$ and $6.10 \pm 1.15$ days, respectively). However, the pre-oviposition period was found longer took more days $(12.47 \pm 0.78$ days $)$ previously at the same temperature (Gurel and Gosterit, 2008). Another species, B. ignitus, however, took similar days $(6.3 \pm 4.0$ days $)$ for pre-oviposition period at the same temperature (Yoon et al., 2002). This differed when increasing hibernation duration from three to four months with bit earlier ( $3.8 \pm 0.7$ days) for $B$. terrestris queen at 28 ${ }^{\circ} \mathrm{C}$ (Amin et al., 2008) and variability existed $(2.44 \pm 0.6$ to $5.75 \pm 0.8$ days) for field collected queens for preoviposition period which might be due to more severe field conditions and high stress for survival (Yeninar et al., 2000).

Temperature significantly affected the production of egg cells by bumblebee queens with highest egg cells produced $(3.10 \pm 0.31)$ at $30^{\circ} \mathrm{C}$. Production of egg cell in first brood with maximum numbers produced at $30{ }^{\circ} \mathrm{C}$ for same species (Amin et al., 2008; Gurel and Gosterit, 2008). However, there existed little variation in cell numbers with previous work. Similarly, the ratio of egg laying and colony production was higher at $30 \pm 0.5^{\circ} \mathrm{C}$ and $60 \%$ relative humidity (Jie et al., 2005). Number of cells produced by field-collected queens was comparatively more than those of laboratory reared which might be due to genetic diversity, competition and other environmental factors to field collected queen's response (Yeninar and Kaftanoglu, 1997; Yeninar et al., 2000; Gosterit and Gurel, 2005).

Temperature also influenced activation and development of ovary in bumblebee queens with an increase of ambient temperature (Vogt et al., 1998; Amin et al., 2008). Similar response to this temperature has been observed for other insects like boll weevil, Anthonomus grandis (Boheman) suggesting $30{ }^{\circ} \mathrm{C}$ as most suitable for such reproductive mechanism but decreased significantly after that (Greenberg et al., 2005). Egg laying of Adoxophyes honmai (Lepidoptera: Tortricidae) significantly affected by temperature with the highest number of eggs laid between $28-30{ }^{\circ} \mathrm{C}$ (Nabeta et al., 2005). $30{ }^{\circ} \mathrm{C}$ influenced significantly the timing of first worker emergence with the shortest period $(27.7 \pm 0.93$ days) as previously observed for both $B$. terrestris and $B$. ignitus. However, the latter species performed well at 27 ${ }^{\circ} \mathrm{C}$ with almost half duration for first worker emergence than former observed (Gurel and Gosterit, 2008; Yoon et al., 2002). Emergence timing of first brood workers play an important role in the development of the colony. Once the first brood worker emerges, they help the queen in the development of subsequent brood and share the workload of the queen.
Number of workers in first brood $(7.9 \pm 0.45)$ were significantly more at $28{ }^{\circ} \mathrm{C}$ which differ as variable temperatures showed no effect at three temperature regimes $\left(24,27\right.$ and $\left.30^{\circ} \mathrm{C}\right)$ (Gurel and Gosterit, 2008). However, there existed insignificant differences in emergence timing of males which were also observed previously for both B. terrestris and B. ignitus (Holland, 2013; Yoon et al., 2002). However, the shortest period of male emergence was at $27{ }^{\circ} \mathrm{C}(71.3 \pm 5.1$ days $)$. Change of the founding queen pheromones and colony control play important role in the initiation of caste production in bumblebee colonies (Cnaani et al., 2000). In social Hymenoptera such as $A$. mellifera and B. hypnorum, juvenile hormone $(\mathrm{JH})$ was found in the determination of castes (Röseler and Röseler, 1974; Rembold et al., 1974).

Emergence period of new queens were significantly affected by temperature with the shortest period at $30{ }^{\circ} \mathrm{C}$ (75.80 \pm 1.82 days). Significant effect of temperature was, however, observed in queen emergence for $B$. terrestris (Gosterit and Gurel, 2005) taking slightly more time (89.7 \pm 6.33 days) than our study. Yoon et al. (2002), for B. ignitus, found the shortest period of queen emergence (80.1 \pm 4.5 days) at $27{ }^{\circ} \mathrm{C}$. Such variation was observed for emergence timing of progeny queens in a colony in the response of temperature (Spark and Collinson, 2007; Bartomeus et al., 2011; Holland, 2013).

Switch and competition point are important stages in colony development of bumblebees, however, we observed insignificant effect of exposure temperatures to these stages in bumblebee biology. Gurel and Gosterit (2008) and Amin et al. (2008) also observed no effect of different rearing temperatures. These points might be endogenously controlled by the queen and insensitive to external temperature.

Exposure of founding queen to the different experimental temperature showed significant variation in the production of workers. Number of workers produced was higher at $28^{\circ} \mathrm{C}(190.10 \pm 7.82)$ than other temperatures. However, multiple conditions vary such response as Amin et al. (2008) found that queens that had artificially hibernated for the duration of three months and given exposure temperature of $28^{\circ} \mathrm{C}$; produced highest workers number $(268 \pm 31.4)$ in the established colonies. Holland (2013) also found a significant effect of temperature on the number of workers produced in the colony. However, Gurel and Gosterit (2008) found insignificant effect of temperature on production of workers with a maximum at $24{ }^{\circ} \mathrm{C}(102.71 \pm 14.30)$. Yoon et al. (2002) when reared B. ignitus at 23,27 and $30^{\circ} \mathrm{C}$ found an insignificant effect on the production of workers, however, workers produced at $27^{\circ} \mathrm{C}$ were greater than other temperatures under study (163.7 \pm 33.3$)$. Insignificant difference existed for male 
production at different temperatures which strengthen our observations for $B$. terrestris has also observed for B. ignitus (Yoon et al., 2002; Gurel and Gosterit, 2008). However, exposure temperature of $36{ }^{\circ} \mathrm{C}$ was identified to produce a maximum number of males in a colony (Amin et al., 2008).

Founded queens exposed to $30{ }^{\circ} \mathrm{C}$ produced significantly higher number of progeny queens $(67.70 \pm 6.72)$ which coincide with previous observations (Gosterit and Gurel, 2005; Holland, 2013). Amin et al. (2008) observed that queens hibernated for three months when reared under short-day conditions and exposed at 36 ${ }^{\circ} \mathrm{C}$ produced $119.3 \pm 16.8$ queens. Our observations differ from that of Gurel and Gosterit (2008) and Yoon et al. (2002) who observed the insignificant effect of rearing temperature on the production of progeny queen in $B$. terrestris and B. ignitus colonies. We observed insignificant variation in the lifespan of the founding queen which has also been observed previously for both $B$. terrestris and $B$. ignitus species (Holland, 2013; Yoon et al., 2002).

\section{CONCLUSIONS}

The present study indicates highest survival and colony initiation rate at exposure temperature of $28^{\circ} \mathrm{C}$ and $30{ }^{\circ} \mathrm{C}$. The initial phase of colony growth, further colony development and reproductive potential of the colony was also observed best at $28-30{ }^{\circ} \mathrm{C}$. We suggest temperature exposure of $28-30{ }^{\circ} \mathrm{C}$ for successful artificial breeding of $B$. terrestris that provide pollination service to greenhouse and tunnel farming system.

\section{ACKNOWLEDGEMENTS}

This research study was financially supported by Higher Education Commission of Pakistan under NRPU scheme No. 20-1697/R\&D/10 5289. We are also thankful to the anonymous reviewers for their suggestions.

\section{Statement of conflict of interest}

Authors have declared no conflict of interest.

\section{REFERENCES}

Ahmad, M., Bodlah, I., Mehmood, K., Sheikh, U.A.A. and Aziz, M.A., 2015. Pollination and foraging potential of European bumblebee, Bombus terrestris (hymenoptera: apidae) on tomato crop under greenhouse system. Pakistan J. Zool., 47: 1279-1285.

Alford, D.V., 1969. A study of the hibernation of bumblebees (Hymenoptera: Bombidae) in southern England. J. Anim. Ecol., 38: 149-170. https://doi. org/10.2307/2743

Amin, M., Suh, S.J. and Kwon, Y.J., 2008. Reproductive responses to photoperiod and temperature by artificially hibernated bumblebee (Bombus terrestris) queens. Entomol. Res., 38: 250-256. https://doi.org/10.1111/j.1748-5967.2008.00181.x

Banda, H.J. and Paxton, R.J., 1990. Pollination of greenhouse tomatoes by bees. Acta Horticult., 288 : 194-198.

Bartomeus, I., Ascher, J.S., Wagner, D., Danforth, B.N., Colla, S. and Kornbluth, S., 2011. Climateassociated phenological advances in bee pollinators and bee pollinated plants. Proc. natl. Acad. Sci. U.S.A., 108: 20645-20649. https://doi.org/10.1073/ pnas. 1115559108

Beekman, M. and van Stratum, P., 1998. Bumblebee sex ratios: Why do bumblebees produce so many males? Proc. R. Soc. London B: Biol. Sci., 265: 1535-1543. https://doi.org/10.1098/rspb.1998.0469

Beekman, M., Stratum, P.V. and Lingeman, R., 1998. Diapause survival and post-diapause performance in bumblebee queens (Bombus terrestris). Ent. Exp. Appl., 89: 207-214. https://doi.org/10.1046/j.15707458.1998.00401.x

Cnaani, J., Robinson, G.E., Bloch, G., Borst, D. and Hefetz, A., 2000. The effect of queen-worker conflict on caste determination in the bumblebee Bombus terrestris. Behav. Ecol. Sociobiol., 47: 346-352. https://doi.org/10.1007/s002650050675

Cnaani, J., Schmid-Hempel, R. and Schmidt, J.O., 2002. Colony development, larval development and worker reproduction in Bombus impatiens Cresson. Insect. Soc., 49: 164-170. https://doi.org/10.1007/ s00040-002-8297-8

Corbet, S.A., Williams, I.H. and Osborne, J.L., 1991. Bees and the pollination of crops and wild flowers in the European Community. Beeworld, 72: 47-59. https://doi.org/10.1080/0005772X.1991.11099079

Cribb, D., 1990. Pollination of tomato crops by honeybees. Bee Craft, 72: 228-231.

Dogterom, M.H., Matteoni, J.A. and Plowright, R.C., 1998. Pollination of greenhouse tomatoes by the North American Bombus vosnesenskii (Hymenoptera: Apidae). J. econ. Ent., 91: 71-75.

Duchateau, M.J. and Velthus, H.H.W., 1988. Development and reproductive strategies in Bombus terrestris colonies. Behaviour, 107: 186207. https://doi.org/10.1163/156853988X00340

Evans, E.C., Burns, I. and Spivak, M.S., 2007. Befriending bumble bees: A practical guide to 
raising local bumble bees. University of Minnesota Extension Service, St Paul, MN, pp. 65.

Free, J.B., 1993. Insect pollination of crops. Academic Press, London-New York, pp. 172-180.

Gosterit, A. and Gurel, F., 2005. Comparison of development patterns of imported and native Bombus terrestris L. (Hymenoptera: Apidae) colonies in the Mediterranean coastal region. Turk. J. Vet. Anim. Sci., 29: 393-398.

Greenberg, S.M., Spurgeon, D.W., Sappington, T.W. and Setamou, M., 2005. Size dependent feeding and reproduction by boll weevil (Coleoptera: Curculionidae). J. econ. Ent., 98: 749-756.

Gurel, F. and Gosterit, A., 2008. Effects of temperature treatments on the bumblebee (Bombus terrestris L.) colony development. Akdeniz Üniv. Ziraat Fakül. Derg., 21: 75-78.

Holland, J., 2013. Colony life history in the bumble bee Bombus terrestris: Interactions, timing and control. Ph.D. thesis, University of East Anglia, Norwich, UK.

Imran, M., Ahmad, M., Naeem, M., Nasir, M.F., Bodlah, I., Nasir, M., and Sheikh, U.A.A., 2017. Effect of different types of boxes on rearing of Bumble bee, Bombus terrestris. Pakistan J. Zool., 49: 169-174. https://doi.org/10.17582/journal. pjz/2017.49.1.169.174

Jie, W., Wenjun, P., Jiandong, A., Zhanbao, G., Yueming, T. and Jilian, L., 2005. Techniques for year-round rearing of Bombus terrestris L. (Hymenoptera: Apoidea) in China. J. Apicult. Sci., 49: 65-69.

Kwon, Y.J., Saeed, S. and Duchateau, M.J., 2003. Stimulation of colony initiation and colony development in Bombus terrestris by adding a male pupa: The influence of age and orientation. Apidologie, 34: 429-437. https://doi.org/10.1051/ apido:2003039

Lopez-Vaamonde, C., Raine, N.E., Koning, J.W., Brown, R.M., Pereboom, J.J.M., Ings, T.C., RamosRodriguez, O., Jordan, W.C. and Bourke, A.F., 2009. Lifetime reproductive success and longevity of queens in an annual social insect. J. Evolut. Biol., 22: 983-996. https://doi.org/10.1111/j.14209101.2009.01706.x

Mitsuhata, M., 2000. Pollination of crops with bumblebee colonies in Japan. Honeybee Sci., 21: 17-25.

Morandin, L.A., Laverty, T.M. and Kevan, P.G., 2001. Effect of bumblebee (Hymenoptera: Apidae) pollination intensity on the quality of greenhouse tomatoes. J. econ. Ent., 94: 172-179.

Nabeta, F.R., Nakai, M. and kunimi, Y., 2005. Effects of temperature and photoperiod on the development and reproduction of Adoxophyes honmai (Lepidoptera: Tortricidae). Appl. Ent. Zool., 40: 231-238. https://doi.org/10.1303/aez.2005.231

Nabhan, G.P. and Buchmann, S.L., 1997. Services provided by pollinators. In: Nature's services: Societal dependence on natural ecosystems (ed. G. Daily). Island Press, pp. 133-150.

Norus, I.C., 2006. Software of SPSS12. SPSS Inc., Upper Saddle River, Prentice Hall, N. J.

Obrycki, J.J. and Tauber, M.J., 1981. Phenology of three coccinellid species: Thermal requirements for development. Annls. Ent. Soc. Am., 74: 31-36. https://doi.org/10.1093/aesa/74.1.31

Omkar, S. and Pervez, A., 2004. Temperaturedependent development and immature survival of an aphidophagous ladybeetle, Propylea dissecta (Mulsant). J. appl. Ent., 128: 510-514.

Perez-Mendoza, J., Weaver, D.K. and Throne, J.E., 2004. Development and survivorship of immature angoumois grain moth (Lepidoptera: Gelechiidae) on stored corn. Environ. Ent., 33: 807-814. https:// doi.org/10.1603/0046-225X-33.4.807

Pervez, A. and Omkar, S., 2004. Prey-dependent life attributes of an aphidophagous ladybird beetle, Propylea dissecta (Coleoptera: Coccinellidae). Biocontr. Sci. Technol., 14: 587-594. https://doi.or $\mathrm{g} / 10.1080 / 09583150410001682313$

Prys-Jones, O.E. and Corbet, S.A., 1991. Bumblebees, $2^{\text {nd }}$ edn. Richmond Publishing Co. Ltd., Slough, UK, pp. 92.

Prŷs-Jones, O.E. and Corbet, S.A., 2011. Bumblebees, $3^{\text {rd }}$ edn. Pelagic Publishing, Exeter.

Rembold, H., Lackner, B. and Geistbeck, I., 1974. The chemical basis of honeybee, Apis mellifera, caste formation. Partial purification of queen bee determinator from royal jelly. J. Insect Physiol., 20: $\quad 307-314 . \quad$ https://doi.org/10.1016/00221910(74)90063-8

Roseler, P. F. and Roseler, I., 1974. Morphological and physiological differentiation of the caste in the bumblebee species Bombus hypnorum (L.) and Bombus terrestris (L.). Zool. Jaharb. Physiol., 78: 100-198.

Sparks, T. and Collinson, N., 2007. Review of spring: nature's calendar project. The Woodland Trust. Available at: https://naturescalendar.woodlandtrust. org.uk/media/1625/2007-spring.pdf (Accessed on 22 September, 2018)

Srivastava, S. and Omkar, S., 2003. Influence of temperature on certain biological attributes of a ladybeetle, Coccinella septempunctata Linnaeus. 
Entomol. Sin., 10: 185-193.

Tanaka, S. and Uemura, Y., 1996. Flexible life cycle of a cockroach Periplenata japonica with nymphal diapause. J. Orthoptera Res., 5: 213-219. https:// doi.org/10.2307/3503596

Tasei, J.N., 1994. Effect of different narcosis procedures on initiating oviposition of prediapausing Bombus terrestris queens. Ent. Exp. Appl., 72: 273279. https://doi.org/10.1111/j.1570-7458.1994. tb01827.x

Velthuis, H.H. and van Doorn, A., 2006. A century of advances in bumblebee domestication and the economic and environmental aspects of its commercialization for pollination. Apidologie, 37: 421-451. https://doi.org/10.1051/apido:2006019

Vogt, F.D., Heinrich, B. and Plowright, C., 1998. Ovary development in bumblebee queens: The influence of abdominal temperature and food availability. Can. J. Zool., 76: 2026-2030. https://doi.org/10.1139/ z98-146

Westerkamp, C. and Gottsberger, G., 2000. Diversity pays in crop pollination. Crop Sci., 40: 1209-1222. https://doi.org/10.2135/cropsci2000.4051209x

Williams, P., 2007. The distribution of bumblebee colour patterns worldwide: possible significance for thermoregulation, crypsis, and warning mimicry. Biol. J. Linn. Soc., 92: 97-118. https://doi. org/10.1111/j.1095-8312.2007.00878.x

Winter, K., Adams, L., Thorp, R.W., Inouye, D., Day, L.,
Asher, J. and Buchmann, S.L., 2006. Importation of non-native bumble bees into North America: potential consequences of using Bombus terrestris and other non-native bumble bees for greenhouse crop pollination in Canada, Mexico and the United States. White paper. North American Pollinator Protection Campaign, San Francisco, California.

Yeninar, H. and Kaftanoglu, O., 1997. Colony development of Anatolian bumblebees (Bombus terrestris) under laboratory conditions. Acta Horticult., 437: 277-281. https://doi.org/10.17660/ ActaHortic. 1997.437.32

Yeninar, H., Duchateau, M.J., Kaftanoglu, O. and Velthuis, H.H., 2000. Colony developmental patterns in different local populations of the Turkish bumblebee, Bombus terrestris dalmatinus. J. Apicult. Res., 39: 107-116. https://doi.org/10.108 $0 / 00218839.2000 .11101030$

Yoon, H.J., Kim, S.E. and Kim, Y.S., 2002. Temperature and humidity favorable for colony development of the indoor-reared bumblebee, Bombus ignitus. Appl. Ent. Zool., 37: 419-423. https://doi.org/10.1303/ aez.2002.419

Yoon, H.J., Kim, S.E., Lee, K.Y., Lee, S.B. and Park, I.G., 2005. Oviposition and colony development of the bumblebee, Bombus ignites and B. terrestris depending on different pollen. Int. J. indust. Ent., 11: 99-105. 